\title{
Comparison of social-ecological resilience between two grassland management patterns driven by grassland land contract policy in the Maqu, Qinghai-Tibetan Plateau
}

\author{
Jianjun Cao ${ }^{\mathrm{a}}$, Mengtian Li ${ }^{\mathrm{a}}$, Ravinesh C. Deo ${ }^{\mathrm{b}, \mathrm{c}}$, Jan F. Adamowski ${ }^{\mathrm{d}}$, Artemi Cerdà ${ }^{\mathrm{e}}$, Qi Feng ${ }^{\mathrm{b}, *}$, \\ Minxia Liu ${ }^{a}$, Jian Zhang ${ }^{a}$, Guofeng Zhu ${ }^{a}$, Xuebin Zhang ${ }^{a}$, Xueyun $\mathrm{Xu}^{\mathrm{a}}$, Shurong Yang ${ }^{\mathrm{a}}$, \\ Yifan Gong ${ }^{\mathrm{a}}$ \\ a College of Geography and Environmental Science, Northwest Normal University, Lanzhou 730070, China \\ ${ }^{\mathrm{b}}$ Key Laboratory of Ecohydrology of Inland River Basin, Alashan Desert Eco-Hydrology Experimental Research Station, Cold and Arid Regions Environmental Engineering \\ Research Institute, Chinese Academy of Sciences, Lanzhou 73000, China \\ c School of Agricultural, Computational and Environmental Sciences, International Centre for Applied Climate Sciences (ICACS), Institute of Agriculture and Environment \\ (IAg \& E), University of Southern Queensland, Springfield, QLD 4300, Australia \\ d Department of Bioresource Engineering, Faculty of Agricultural and Environmental Science McGill University, Québec H9X 3V9, Canada \\ e Soil Erosion and Degradation Research Group, Department de Geografia, Universitat de Valencia, Blasco Ibanez, 28, 46010 Valencia, Spain
}

\section{A R T I C L E I N F O}

\section{Keywords:}

Resilience

Land use policy

Multi-household management pattern

Single-household management pattern

Social-ecological system

\begin{abstract}
A B S T R A C T
Embraced for decision-making, resilience has evolved as a meaningful term in areas such as ecology, the economy and society. After a policy of grassland contracts was implemented on the Qinghai-Tibetan Plateau, two grassland management patterns evolved: the multi-household management pattern (MMP) and the singlehousehold management pattern (SMP). Within a resilience-driven perspective, this study compared the outcomes of these grassland management patterns by measuring their effects on the resilience of grazing, ecological, economic and social systems. Resilience indicators for each of the four systems were: grazing system (grazing space, transhumance, water source and reproduction); ecological system (vegetation including cover, biomass, species richness and soil properties including $\mathrm{pH}$, organic carbon, total nitrogen and total phosphorus); economic system (income, expenditure and infrastructure) and the social system (health, assistance, social relations, cultural inheritance and institutional arrangements). In order to provide a social-ecological resilience framework for the two grassland management patterns, a decision support tool was applied to approximately gauge the resilience of each indicator. The results showed that each of the four systems under the MMP had a greater degree of resilience than the SMP, and that the overall resilience of the MMP was estimated at 5.8 units compared to about -5.8 units for the SMP. The relative success of the MMP was seen to rest largely on the maintenance of traditional management practices, social networks, trust and the low cost and high efficiency of informal institutions, which acted to reduce the risk of unsustainable development of ecological and social systems. The important take-home lesson from this study is that contracting of grasslands to private entities on the Qinghai-Tibetan Plateau, and in the rest of the world where similar land management practices exist, must be undertaken with caution.
\end{abstract}

\section{Introduction}

The term 'resilience', pioneered by Holling (1973), refers to the propensity of a natural system to retain its organizational structure and to continue to be reasonably productive following a significant perturbation, or the varied rate of return of a variable after such a perturbation is applied to the system (Vogel et al., 2012). Contextualized as a self-organizational process, resilience is meant to include the interaction between different structures and physical processes, leading to the evolution and development of the system regardless of the initial conditions (Gunderson, 2000). Although the definition of resilience adopted by professionals working in conservation, policy and the sciences has expanded (Brown and Williams, 2015; Carpenter et al., 2001; Ciftcioglu, 2017; Fisichelli et al., 2016; Oliver et al., 2015a), most of the resilience-driven thinking used as a guiding framework for addressing sustainability challenges tends to start with the premise that the social

\footnotetext{
* Corresponding author.

E-mail address: Qifeng@lzb.ac.cn (Q. Feng).
} 
and ecological aspects are not identifiably separate (Cumming et al., 2005; Rist et al., 2014). Using resilience-thinking, multiple, cross-scale interactions, ecological thresholds and feedbacks in a social-ecological system (SES) are likely to be better understood, allowing resource managers and policy makers to maintain the flexibility necessary to respond to uncertainty and change (Cumming et al., 2005; Miller et al., 2010; Nelson et al., 2007; Plummer and Armitage, 2007).

In ecological sciences as applied in the present research paper, resilience refers to the ability of a multi-stable system to absorb different magnitudes of perturbations in order to resist 'regime shifts' and retain their functions and structure post-stress while maintaining the systems' development (Bengtsson et al., 2003; Gallopín, 2006; Nelson et al., 2007; Ng et al., 2015). Ecological resilience is evolving into a credible paradigm for sustainable policy development, particularly for better environmental management to help preserve natural capital in a rapidly globalizing world (Spears et al., 2015). The diversity of species and their specific responses to the variation, heterogeneity, and redundancies and connectedness of habitats, as well as governance and management plans are known to influence the resilience of an ecosystem (Ayala-Orozco et al., 2016; Bengtsson et al., 2003; Cutter et al., 2008; Nyström et al., 2000; Oliver et al., 2015b; Sara and Nico, 2015). In the social sciences, resilience is often applied to describe the ability of groups or communities to buffer disturbances, and consequently, to self-organize, learn and adapt despite the existence of adversity emanating from social, political and environmental changes (Luthar and Cicchetti, 2000). An ability to learn through trust and engagement are thus the cornerstones of social resilience (Gunderson, 2000; Lebel et al., 2006). Good social relationships (e.g., networks and individuals and groups in communities), and improvements in the awareness of risk, disaster management plans, insurance coverage, information sharing, local environmental knowledge and skills and access to resources are also relevant for enhancing the resilience of a given society (Berkes and Jolly, 2000; Cutter et al., 2008; Olsson et al., 2004; Paton et al., 2001; Tompkins and Adger, 2004). In the field of inter-disciplinary sciences, resilience is used to emphasize the functioning of an SES that involves inter-linked or coupled systems of people and nature, vital to the health of ecosystems, human wellbeing and resource equitability for current and future generations (Ciftcioglu, 2017; Nelson et al., 2007; Walker et al., 2002; 2006;). A resilient SES is thus likely to continually moderate and consequently adapt, while remaining within a stable domain, because natural resource managers are able to learn and actively adapt relevant ecosystem management policies and act to prevent unsustainable and undesirable development trajectories (Folke et al., 2010; Olsson et al., 2004; Spears et al., 2015). A disturbance or a crisis can sometimes be regarded as an opportunity for novelty, innovation and development in a resilient SES (Folke, 2006; Folke et al., 2010). A few previous studies have attempted to identify the characteristics of resilient systems from a broad socioeconomic perspective (Oliver et al., 2015a), but the research on social-ecological resilience is still very much in an exploratory phase (Folke, 2006), and often evaluated independently by social scientists and ecologists (Cao et al., 2014a).

Human actions and nature form a tightly coupled system, so an appropriate degree of natural resource management is sometimes warranted to increase the resilience of an ecosystem to exogenous factors such as stress or disturbances (Chambers et al., 2014). This can also assist in the promotion of the overall well-being of humanity (Ayala-Orozco et al., 2016). A transformation of strategies to increase resilience from the conceptual stage to the implementation stage is rather difficult or even impossible in some circumstances, due to the mismatch across different disciplines and scales, and underlying field conditions. Therefore, surrogate resilience indicators can be defined and applied to the entire spectrum of SES (Carpenter et al., 2001; Fisichelli et al., 2016). Empirical applications of resilience theory can contribute to different policy and management perspectives by evaluating the potential consequences of different manipulations made by policy makers and natural resource managers (Cumming et al., 2005).
Many case studies on resilience, and especially in ecological sciences, provide examples of these applications including: coral reefs (Hughes et al., 2003; McCulloch et al., 2012; Mumby et al., 2007), pollinator communities (Sara and Nico, 2015), grasslands (Craine et al., 2013; Klimeš et al., 2013; Looy et al., 2016; Vogel et al., 2012), forests (Scull et al., 2016), conservation of biodiversity (Sgrò et al., 2011), and fauna (Knapp et al., 2005). In social sciences, studies have focused on the resilience of grasslands to institutional arrangements (Schermer et al., 2016), resilience of water resource management to government policy (Schlüter and Pahl-wostl, 2007), and the resilience of farmland to traditional land management knowledge (Assefa and Hans-Rudolf, 2016). In SES, studies have focused on the resilience of natural resources management (Tompkins and Adger, 2004) and agricultural systems (Ciftcioglu, 2017; Darnhofer, 2014) to climate change, and on the resilience of SES to coastal disasters (Adger et al., 2005). Efforts to measure and assess the resilience within these diverse fields have stimulated significant research interests applied through an array of qualitative and quantitative approaches (Quinlan et al., 2016).

However, in previous studies performed on the resilience of grassland systems, most of the research focused only on the effects of species richness (Kühsel and Blüthgen, 2015), mowing in different seasons (Klimeš et al., 2013), fire (Anderies et al., 2002), or management issues (e.g., mowing frequency, fertilizer applications) (Vogel et al., 2012), and seldom considered the effects of variation in grassland management (such as the grazing space or transhumance) induced by policy on SES, such as grassland management modifications in Maqu, on the eastern Qinghai-Tibetan Plateau (QTP). Historically, the herders of Maqu engaged in transhumant pastoralism with yak and Tibetan sheep based on collective management, an apparently environmentally sustainable use of the land (Cao et al., 2011; Yan et al., 2005). However, in the 1990s grassland management in this region, as in other countries around the world, was changed significantly through a set of policies of grassland contracts (Cao et al., 2011; Harris, 2010; Veeck et al., 2015) due to the influence of socio-political circumstances (Andersen et al., 2014; Singh et al., 2013). Although all winter grasslands were required to be contracted to single-households, many of the herders were unwilling to operate in isolation because of their history of collective nomadism and dependence on the collective lifestyle (Cao et al., 2011). With the implementation of grassland contract policy, two grassland management patterns evolved: (1) a multi-household management pattern (MMP) where the grassland was jointly managed by two or more households without fences between the individual household pastures, and (2) a single-household management pattern (SMP) where grassland was managed by individual households with fences demarcating the ownership, and the scope and space of the available rangeland was also inadvertently reduced (Yeh and Gaerrang, 2011; YontenNyima, 2012). At present, most of the MMP households have summer and winter pastures, while most of the SMP households have only one pasture for year-round use (Cao et al., 2013), a practice that is consistent with the one operating in Jammu and Kashmir, Northern India (Singh et al., 2013). Stocking rates (i.e., number of sheep per ha) were the same for both MMP and SMP and were mandated, monitored and enforced by Grassland Supervisor Stations (Cao et al., 2011).

In this paper, our primary aim is to explore the influence of the above mentioned two different grassland management patterns on grazing, ecological, economic, and social resilience, and to determine which grassland management pattern can maintain higher resilience of local SES in Maqu County.

\section{Materials and methods}

\subsection{Study area}

Maqu County, in Gansu province $\left(101^{\circ}-102^{\circ} \mathrm{E}, 33^{\circ}-34^{\circ} \mathrm{N}\right)$, is located on the eastern QTP and traverses the boundary of Qinghai and Sichuan provinces in China. Its altitude ranges from 2900 to $4000 \mathrm{~m}$ and annual 
rainfall is from 450 to $780 \mathrm{~mm}$. The average annual temperature is $1.8^{\circ} \mathrm{C}$ with an average monthly low of $-10.7^{\circ} \mathrm{C}$ in January and a high of $11.7^{\circ} \mathrm{C}$ in July. The maximum air temperature during the growing season can reach $29^{\circ} \mathrm{C}$, and there are, on average, 270 frost days annually. The grassland area of Maqu County covers about $87 \times 10^{4}$ ha, and $59 \%$ is classified as alpine meadow. This area is commonly known as the 'water tower' of the plateau, because the surface runoff from this region accounts for about $58.7 \%$ of the total runoff to the Yellow River. There are seven villages and one town (a sub-administrative unit) in Maqu County with a total population of 57,000 in 2015 . About $89 \%$ of the people are herdsmen. The annual production value related to animal husbandry is $47 \times 10^{6} \mathrm{RMB}$, constituting about $94 \%$ of the agricultural production value in this study area. Currently, about $90 \%$ of a herder's income is derived from the trade of livestock and their byproducts; the remaining $10 \%$ comes from the sale of medicinal materials and other goods (Cao et al., 2011).

\subsection{An operational model for the grazing, ecological, economic and social} system

There are theoretically non-linear associations and influences among the grazing, ecological, economic and social systems, and social and economic systems affect the grazing system directly via socialeconomic policies. Since the grazing system, which includes the grazing scale, foraging, drinking, reproductive behaviors and the transhumance of the livestock, has been affected by the grassland contract policy, we would expect the ecological system, which includes the vegetation and soil, to adjust in response to these changes. Consequently, a flow-on effect is expected to ultimately be realized in the local economic and social systems, owing to their strong coupling with the overall ecological system. Fig. 1 shows the grazing, ecological, economic and social systems within an SES.

\subsubsection{Indicator selection for each system in SES}

Based on several studies (e.g., Ayala-Orozco et al., 2016; Briske et al., 2008; Carpenter et al., 2001; Chen and Zhu, 2015; Ciftcioglu, 2017; Cumming et al., 2005; Klimeš et al., 2013; Plummer and Armitage, 2007), and the insights gained from our earlier research on the measured differences between MMP and SMP, we have developed a comprehensive set of 20 indicators to measure the resilience of each system as follows:
2.2.1.1. Grazing system indicators. (i) Grazing space: to measure livestock mobility; (ii) Transhumance: to assess the variety of plants being grazed as some are very important for livestock health; (iii) Water source: water availability for herders and livestock; (iv) Reproduction: to assess inbreeding, which reduces genetic diversity and the long-term health of the livestock.

2.2.1.2. Ecological system indicators. (v) Vegetation (plant cover, biomass and species richness) and soil characteristics ( $\mathrm{pH}$, soil organic carbon content, soil total nitrogen and soil total phosphorus): to measure the ecological effects of different grassland management patterns.

2.2.1.3. Economic system indicators. (vi) Income and expenditure: to measure the livelihood of herders; and (vii) Infrastructure: to assess the herder's welfare.

2.2.1.4. Social system indicators. (viii) Equity: opportunities available for herders to access natural resources and to participate in decisionmaking; (ix) Health: the outcome of changes to the herder's lifestyle; (x) Assistance: to assess help available to herders when natural hazards or manmade disasters occur; (xi) Social relations: to measure the herder's social network and conflicts among herders; (xii) Cultural inheritance: the status of traditional knowledge vital to the protection of grassland, wildlife, livestock and herder's health; (xiii) Institutional arrangements: costs and benefits of formal and informal institutions.

\subsubsection{Scoring criteria of the indicators}

In this study, the resilience of each system was gauged using a decision support tool known as the Mauri Model. This model is based on the economic, environmental, social and cultural well-being of the Māori, the indigenous people of New Zealand (Peacock et al., 2012). Typically, a set of scoring metrics is devised in the Mauri Model to assess each factor based on the nature of the project. An integer value from -2 to +2 , representing the change in a Mauri's well-being or 'life force', is then assigned for each metric. A ' 2 ' represents the full restoration of a Mauri's well-being; 1 is a partial restoration; 0 indicates no change; -1 is a partial degradation and -2 is a complete degradation. Although the model framework was originally based on the Māori culture, it is a plausible technique that can be applied to other cultures as a tool for societal assessments (Peacock et al., 2012). For this

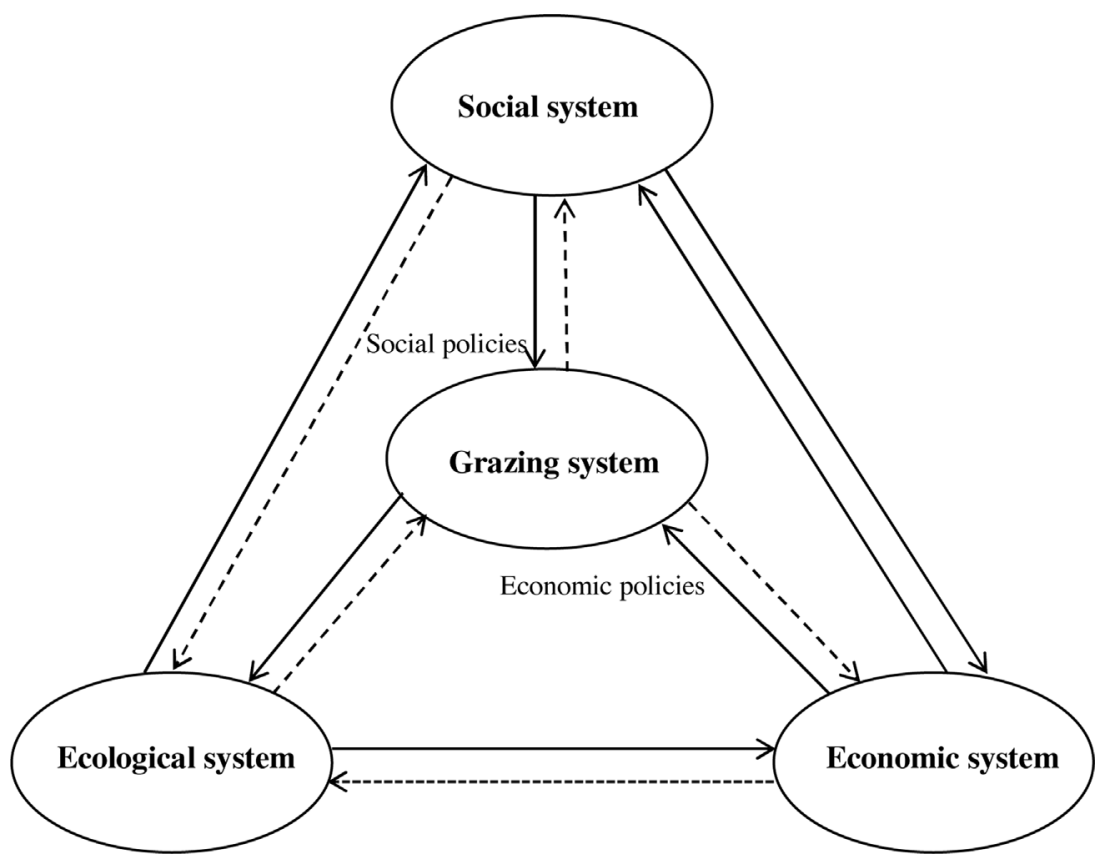

Fig. 1. Conceptual model of the social-ecological system. Solid arrows indicate a direct effect, dashed arrows an indirect effect, and the twoway arrows show an interaction. 
study, where the Mauri Model was used, we have assigned the values for 'full restoration to complete degradation', as follows:

\subsection{Grazing space}

relatively large +1 , relatively small -1 ; Transhumance: with seasonal transhumance +1 , without -1 ; Water sources: more than three +1 , less than three -1 ; Reproduction: without inbreeding +2 , with inbreeding -2; Vegetation and soil characteristics: higher biomass, cover, species richness but lower $\mathrm{pH}$ value +1 , lower biomass, cover, species richness but higher $\mathrm{pH}$ value -1 ; Income and expenditure: high income +1 , low income -1 ; Infrastructure: with +1 , without or less of it -1 ; Equity: equity +2 , inequity -2 ; Health: relatively good health +1 , poor health -1 ; Assistance: exists +2 , absent -2 ; Social relations: good +1 , poor -1 ; Cultural inheritance: strong +2 , weak -2 ; Institutional arrangements: with +2 , without -2 .

The total resilience of each system can be calculated as (Peacock et al., 2012):

$S_{j}=\frac{\sum w_{j} s_{j}}{100}$

where $S_{j}$ represents the total resilience of each system, $w_{j}$ is the weight of each indicator in the system, and $s_{j}$ is the corresponding assigned value of the indicator.

For the entire system for either the MMP or the SMP, total resilience can then be calculated as (Peacock et al., 2012):

$S_{T}=\frac{\sum W_{j} S_{j}}{100}$

where $S_{T}$ is the total resilience of the four systems and $W_{j}$ is the weight of each system.

It is important to mention that in this study, $w_{j}$ is regarded as a constant value because each indicator is highly correlated while $W_{j}$ is a variable because each system has a different role in the local SES. According to the role of each system in the SES as described above, the grazing and ecological systems are given weights of $50 \%$ and $30 \%$, respectively, while the social and economic systems are weighted at $10 \%$ each.

\subsection{Data acquisition and analysis}

Extensive data were acquired at three different times: 2005, 2009-10 and 2016. In 2005, a total of 525 herders were surveyed in order to better understand the social, economic and cultural differences between the MMP and SMP. In 2009 and 2010, differences in vegetation (i.e., biomass, species richness and cover) were compared between 30 MMP winter pastures and 30 SMP winter pastures in five sites with both MMP and SMP (Table 1) to exclude the effect of topographic factors (Cao et al., 2011, 2013; Yang, 2012).

For each selected MMP, the number of households was greater than three; otherwise the grazing conditions were too similar to SMP (Cao, 2011). Winter pastures were selected because they often bear a higher grazing intensity than the summer pastures due to the extended usage period and reduced spatial mobility after privatization (Fassnacht et al., 2015). Each site has been continuously grazed since the

Table 1

The number of MMP and SMP winter pastures sampled at each site.

\begin{tabular}{lll}
\hline Sites & $\begin{array}{l}\text { Number of sampled } \\
\text { MMP }\end{array}$ & Number of sampled SMP \\
\hline Site $1\left(101^{\circ} 41^{\prime} \mathrm{E}, 33^{\circ} 45^{\prime} \mathrm{N}\right)$ & 2 & 2 \\
Site $2\left(102^{\circ} 5^{\prime} \mathrm{E}, 33^{\circ} 41 \mathrm{~N}\right)$ & 5 & 5 \\
Site $3\left(101^{\circ} 58^{\prime} \mathrm{E}, 34^{\circ} 1 \mathrm{~N}\right)$ & 9 & 14 \\
Site $4\left(101^{\circ} 48^{\prime} \mathrm{E}, 34^{\circ} 0^{\prime} \mathrm{N}\right)$ & 6 & 5 \\
Site $5\left(102^{\circ} 4^{\prime} \mathrm{E}, 33^{\circ} 33^{\prime} \mathrm{N}\right)$ & 8 & 4 \\
\hline
\end{tabular}

implementation of the grassland contract policy, and has the same stocking rate. Within each sampling pasture, the grassland plant communities were assessed using three $50 \times 50 \mathrm{~cm}$ quadrats.

In 2016, in each previously sampled pasture soil samples to a depth of $30 \mathrm{~cm}$ were taken from 3 plots $(10 \mathrm{~m} \times 10 \mathrm{~m}) 10 \mathrm{~m}$ apart, with 3 soil samples spaced along the diagonal (both ends and midpoint) in each plot, to investigate the differences in soil nutrients between the MMP and SMP. During the survey we found that a few of the MMP sites had transformed into SMP sites by 2016 . However, based on the comprehensive surveys, the conversion from MMP to SMP had taken place in 2014, and was therefore expected to produce little change in the stable variables (e.g., soil nutrients).

Ground cover was estimated using the Braun-Blanquet scale, and species richness and biomass was expressed as the mean of the species count for each surveyed plot, and as dry weight, respectively (further details are reported by Cao et al., 2013). Soil pH was determined using a 2.5:1 water to air-dried soil ratio and a standard $\mathrm{pH}$ meter, and soil organic content (SOC) was determined with wet dichromate oxidation using an air-dried homogenized subsample of $0.2 \mathrm{~g}$ soil and titrated with iron sulphate $\left(\mathrm{FeSO}_{4}\right.$ ) (Qin et al., 2016). Total soil nitrogen (TON) and total soil phosphorus (TOP) were determined using a Smartchem 140 Automatic Chemistry Analyzer (AMS/westco, Italy) (Chen et al., 2016).

An intercomparison of the grazing, economic and social systems between the MMP and SMP was primarily analyzed using qualitative approaches, while statistical differences in the ecological systems were identified using quantitative methods. Data were analyzed using SPSS 18.0 statistical software running on a MAC system (IBM, New York, USA). All data were expressed as mean values \pm standard deviation (SD), and a one-way analysis of variance was applied to determine the significance of differences in various measured parameters at a significance level $\mathrm{p}<0.05$ in terms of the different grassland management types.

\section{Results}

Of the 525 interviewees, a total of 489 subjects were men, which reflected the local society and the generally low social status of women. The mean age of the interviewees was about 38.5 years and ranged from 18 to 75; 299 participants were illiterate, and 188 participants had primary school level education; 417 participants had adopted the MMP, while the remaining participants had adopted the SMP (Cao et al., 2011).

With the exception of soil $\mathrm{pH}$, values of the measured ecological parameters were all higher under MMP than SMP. According to Eqs. (1) and (2), and the assigned weight of each indictor, the total resilience of the systems in the MMP was found to be 5.8 compared to a value of -5.8 for the systems in the SMP (Table 2).

\section{Discussion}

\subsection{Grazing and ecological systems}

The SMP, with its limited grazing area imposed by fencing, could result in reduced mobility of the livestock compared with the MMP (Cao et al., 2013; Fernandez-Gimenez, 2002; Yan et al., 2005; Yeh and Gaerrang, 2011). In accordance with earlier studies, with limited mobility, trampling caused by livestock increased (Ao et al., 2008; Dlamini et al., 2014; Klein et al., 2011; YontenNyima, 2012), and seed dispersal, propagation and plant regeneration declined (Briske et al., 2008; Ciftcioglu 2017; Liu et al., 2003; Olff and Ritchie, 1998), which in turn will cause a reduction in shoot and root biomass as well as species richness (Carpenter et al., 2001; Klimeš et al., 2013; Vogel et al., 2012). With reduced biomass, SOC, TON and TOP accumulation is also likely to decline, thus reducing stored and available soil nutrients (Grosse et al., 2011; Hirsch et al., 2016; Li and Zhang, 2009; Ma et al., 2016; 
Table 2

Resilience of grazing, ecological, economic and social systems for the MMP and the SMP.

\begin{tabular}{|c|c|c|c|c|}
\hline \multirow[t]{2}{*}{ Indicators } & \multirow[t]{2}{*}{ MMP } & \multirow[t]{2}{*}{ SMP } & \multicolumn{2}{|c|}{ Scoring } \\
\hline & & & MMP & SMP \\
\hline \multicolumn{5}{|l|}{ Grazing system } \\
\hline -Grazing area & Large & Small & 1 & -1 \\
\hline -Transhumance & yes & no & 2 & -1 \\
\hline -Water source & Three or more & One or none & 1 & -1 \\
\hline •Reproduction & Without inbreeding & Inbreeding & 2 & -2 \\
\hline \multicolumn{5}{|l|}{ Ecological system } \\
\hline \multicolumn{5}{|l|}{ Plant } \\
\hline •Biomass (g) & $42.34 \pm 2.38^{\mathrm{a}}$ & $34.47 \pm 2.26^{\mathrm{b}}$ & 1 & -1 \\
\hline - Cover (\%) & $91.00 \pm 0.01^{\mathrm{a}}$ & $87.00 \pm 0.01^{b}$ & 1 & -1 \\
\hline -Species richness & $18.35 \pm 0.53^{\mathrm{a}}$ & $15.00 \pm 0.58^{\mathrm{b}}$ & 1 & -1 \\
\hline \multicolumn{5}{|l|}{ Soil } \\
\hline$\bullet \mathrm{pH}$ & $6.86 \pm 0.79^{\mathrm{a}}$ & $7.02 \pm 0.67^{\mathrm{b}}$ & 1 & -1 \\
\hline -SOC (g kg-1) & $47.27 \pm 27.27^{\mathrm{a}}$ & $42.96 \pm 18.30^{b}$ & 1 & -1 \\
\hline -TON (g kg-1) & $4.60 \pm 2.47^{\mathrm{a}}$ & $4.28 \pm 1.91^{\mathrm{b}}$ & 1 & -1 \\
\hline -TOP (g kg-1) & $0.77 \pm 0.32^{\mathrm{a}}$ & $0.73 \pm 0.32^{\mathrm{b}}$ & 1 & -1 \\
\hline \multicolumn{5}{|l|}{ Economic system } \\
\hline •Income (RMB) & High & Low or average & 1 & -1 \\
\hline -Expenditure (RMB) & Low & High & 1 & -1 \\
\hline •Infrastructure & Better & Worse & 1 & -1 \\
\hline \multicolumn{5}{|l|}{ Social system } \\
\hline$\bullet$ Equity & Fair & Unfair & 2 & -2 \\
\hline$\bullet$ Health & Good & Average & 1 & -1 \\
\hline -Assistance & Yes & Absent & 1 & -1 \\
\hline -Social relations & Good & Average & 1 & -1 \\
\hline -Culture inheritance & Better & Worse & 2 & -2 \\
\hline $\begin{array}{l}\text {-Institutional } \\
\text { arrangement }\end{array}$ & Yes & Absent & 2 & -2 \\
\hline
\end{tabular}

Note: lowercase $\mathrm{a}$ and $\mathrm{b}$ means that the measured parameters are significantly different between MMP and SMP. Part of the data came from Cao et al. (2011, 2013), Chen and Zhu (2015), Cai and Li (2016), Ekpo et al. (2008) and Kerven et al. (2016).

You et al., 2014). Because of the nutrient-rich soils in the MMP, this grazing pattern is likely to have a lower $\mathrm{pH}$ than the SMP, since the contribution of decaying organic materials can lead to the release of organic acids (Brady, 1990).

The differences in above-ground vegetation and soil nutrients between the MMP and SMP could confirm that trampling has adverse effects on plant and soil. Similar to soil nutrient trends, biomass, plant cover and species richness under the MMP are significantly greater than the SMP (Table 2). Changes in soil and vegetation are therefore important facets of the ecosystem's response to the modified grazing patterns and understanding this is essential for conservation management and successful restoration (Coiffait-Gombault et al., 2012; Pazkagan et al., 2014). In addition, with limited livestock mobility under the SMP, mortality rates of livestock can also be a significant issue as, in the event of a natural disaster, they are unable to move to other areas for resources (Cai and Li, 2016; Nkedianye et al., 2011).

In the MMP, with its higher total count of transitional movements and the long distance (i.e., $30 \mathrm{~km}$ or more) between summer and winter pastures, livestock graze on higher quality fresh plants. This may be more important than the total quantity of available vegetation because such a diet results in a balance in macro and micro minerals, which is very favorable in terms of livestock heath and production (Al-Tabini et al., 2012; Kerven et al., 2016; Yoshihara et al., 2013).

In general, the more plentiful the water sources, the lower the degradation of the grassland. In a herder's opinion, both the water source and the grassland surrounding it can be damaged by over-utilization, and the smaller water sources could simply dry up after several years of use. Without a sufficient local water supply, the livestock need to travel further for drinking purposes. Under the MMP, there are often three or more water sources in the grassland, while for the SMP, there is only one, or possibly no water source at all available to livestock. In this case, SMP households have to dig wells, leading to over-exploitation of underground water and thus affecting the safety of water resources in downstream areas of the Yellow River. Therefore, reconstruction of the proportion of the seasonal rangeland area may be an effective strategy to prevent serious degradation of rangeland and to protect the water sources in this alpine region (Dong et al., 2015).

Inbreeding or the freedom of gene exchange among the livestock appears to have been hindered by the fences, and this could lead to a decline in the rate of mating, conception and prevention of miscarriages commonly found on the QTP by Cai and Min (2003) and Chen and Zhu (2015). Based on Table 2 and the rules of calculation described above, we can infer that the resilience of the grazing and ecological systems in the MMP is estimated to be 2.5 and 2.1, respectively, while for the SMP, the values are about -2.5 and -2.1 , respectively. Compared with the other indicators in the grazing system, inbreeding is a more serious issue for the SMP, so in order to enhance the resilience of the SMP, or to close the resilience gap between the MMP and SMP, more strategic measures (such as introducing stud stocks) should be adopted to prevent the inbreeding of livestock.

\subsection{Economic systems}

Based on our previous study, we found that SMP households were likely to spend more than MMP households on fence construction (2500 RMB $\mathrm{y}^{-1}$ ) and sheepdog breeding (1116 RMB $\mathrm{y}^{-1}$ ). This is because SMP households were more likely to be widely scattered and thus unable to share expenses with neighbors (Cao et al., 2011). Therefore, livelihood conditions are likely to improve when the SMP is united into the MMP. Moreover, the larger the total household size, the greater the economic benefits (Chen and Zhu, 2015). It is important to note that since the average household population was the same for the SMP and MMP, the per capita income was higher and unit production cost was lower for herders within the MMP. Generally, it was also true that the wealthier households were able to protect their assets by purchasing their inputs (e.g., water and feed) if their livelihoods were threatened (Robinson et al., 2015). Several other economic benefits of the MMP system may be realized, although they are difficult to quantify in absolute terms. For example, in the year 2008, a total of 18 cattle stolen from one family at their summer grassland were found several days later. However, since single-family residents only had a single relationship as a result of the scattered residences, timely on-site assistance was not available to them when they experienced similar issues (for more details see Cao et al., 2011). Such situations, which could translate into better returns, indicate a broader economic benefit of the MMP compared with the SMP.

In recent years, a specialized and intensified livestock production system was developed to help integrate the regional economy into the global marketplace (Perz et al., 2012). MMPs with more than 10 households were more likely to be able to take advantage of this new system since their residential sites were concentrated which facilitated the provision of better infrastructure (Cao et al., 2011), such as roads, solar power, water supply and sheds. Such infrastructure were likely to help herders to more conveniently connect with the market, increase their sales and improve their quality of life as well as allow their livestock to survive the severe winter weather conditions on the QTP. Even without government assistance, the MMP households exhibited an excellent ability to build up basic infrastructure important for the physical and mental health of their herders (e.g., a basketball court and hippodrome), which provided a more sustainable work life, especially for the younger herders. Infrastructure under the MMP had a higher score than the SMP (see Table 2).

Through this study, we inferred that the resilience of the economic system is about 0.3 for the MMP and about -0.3 for the SMP. It is thus construed that if the SMP households continued to manage their grasslands by means of fences, it may be very difficult to enhance their economic resilience unless the government is able to provide sufficient assistance. 


\subsection{Social systems}

Previous studies indicated that MMP households can access grassland resources (including, but not limited to water) more equitably for livestock than the SMP (Cao et al., 2011), and have the distinct advantage that herders can adopt collective actions (Chen and Zhu, 2015). Thus, the MMP has enhanced bargaining powers for resource exploitation and decision-making capabilities compared to the SMP (Cao et al., 2011). From the same standpoint, Rocamora-Montiel et al. (2014) discovered that the participation in, and implementation of, agri-environmental measures by farmer associations were more effective than by individual farmers. With less access to additional resources and alternative sites, the SMP had to forgo a number of traditional disaster relief mechanisms which are available to the MMP (FernandezGimenez et al., 2002; Robinett et al., 2008; Tang and Gavin, 2015; Yeh, 2013). Furthermore, the reduced availability of fodder and water in the SMP can contribute to an increase in the workload of women (Vij and Narain, 2016), since women of QTP are traditionally responsible for grazing and housework. Although the health of the herders was not precisely measured in this study, evidence from others studies (Ekpo et al., 2008; Kerven et al., 2016) suggested that the herders in the SMP were less healthy than those in the MMP, mainly because the SMP herders were less active, had lower protein intake, and their lives in a generally remote pastoral region was relatively boring, lonely and potentially dangerous.

The availability of mutual assistance was very common in the MMP. In some cases, such as snow storms, freezing temperatures and hail, households were likely to lose all their livestock and therefore all their capital. If this happened in the MMP, those who lost their livestock were often helped by the others. In addition, in the MMP, there was a certain amount of pasture land reserved for the commons and generally used only for sheep or old, weak cattle in the winter season. Those who used the commons for other purposes had to give a certain number of livestock for collective compensation, which could be used as welfare funds. These funds helped poorer households within the MMP or even households outside the MMP (Cao et al., 2011). This demonstrates a good sense of social cohesion.

With fewer fences, the social system of the MMP clearly depends on the maintenance of good relationships among neighbors and reinforces high connectivity among the herders. In general, with more fences, there is a chance that conflicts may increase between neighbors (Mcgahey, 2011; Cao et al., 2011; Chen and Zhu, 2015). Due to more amicable and functional relationships in the MMP, cooperation is very common among households, and this can promote sharing among the herders of various kinds of resources, such as labor, pasture, and food (Wang et al., 2016). Based on our previous survey, if one herder could look after three household's livestock, then an estimated 12,000 RMB could be saved by reducing the working costs (e.g., motorcycles used on the farm). Building trust in social networks is a fundamental tool for the self-organizing and the collective actions needed for the management of resilience (Biggs et al., 2012; Lebel et al., 2006).

Local traditional knowledge, a cumulative body of knowledge applied and developed via observations of local resource users and their respective practices for ecosystem management, is an important source of scientific information mobilized through social networks (Andersen et al., 2014; Olsson et al., 2004). Indigenous Tibetans have developed many cultural traditions via the art, literature and entertainment mediums, as well as via education and medicinal practices (Tu et al., 2011). The traditional Tibetan cultures contain alternative knowledge and perspectives that have contributed significantly to the conservation of wild fauna and flora. Their habitats and ecosystems will continue to be the basis for a sustainable way of promoting a harmonious relationship between humans and nature by respecting and protecting all living beings (Anderson et al., 2005; Foggin, 2012; Salick et al., 2007; Shen et al., 2012; Zhang and Miao, 2007).

Flanagan and Laituri (2004) depicted the importance of incorporating culturally specific information into various resource management decisions. MMP households are considerably better at sharing knowledge based on trial and error management practices within the community by cultural transmission (Franco and Luiselli, 2014) than the SMP (Cao et al., 2011; Chen and Zhu, 2015). With the gradual disappearance of traditional culture, younger generations have not learned about traditional resource governance and management first hand, which can be detrimental to the protection of nature and its resources (Tang and Gavin, 2015). Institutional arrangements are also very important for driving environmental change and shaping social behavior and the outcome of natural resource management (Franzén et al., 2015). Schermer et al. (2016) suggested institutions often include three different elements: regulatory, normative and cultural-cognitive. Regulatory elements involve the capacity to establish coercive regulations and laws; normative elements are morally governed to involve the creation of binding expectations in order to follow social obligations; and culture-cognitive elements involve the creation of shared understandings that are taken for granted.

In the case of the MMP there are many kinds of informal institutions including those that are flexible, responsive, multilevel and diverse, all of which can promote the resilience of social-ecological systems (Adger, 2000). For example, to balance the relationship between livestock numbers and grassland capacity, MMP households enacted strict regulations to limit stocking rates that each household had to adhere to. Inspections of livestock numbers are made twice each year by MMP representatives (Cao et al., 2011). If one household decides to settle in town, a common phenomenon across the QTP (Du and Zhang, 2013; Ptackova, 2011; Yeh and Gaerrang, 2011), the right to use its grassland must be transferred to households within the MMP first, and the rental prices must be lower than the average level. If Household A has fewer people but has more grassland than Household B, the number of livestock of Household A may not reach the contracted number. Therefore, the grassland from Household A can be rented to Household B. Furthermore, the time of transhumance should be the same and rules regarding the prohibition of stealing and gambling can greatly influence members within the MMP (Cao et al., 2011). These informal institutions of the MMP perform with high efficiency and at a generally low cost.

For the SMP, decisions about when and where to graze, and how to comply with regulations pertaining to the grazing restrictions or bans are left at the discretion of the herders (Hua and Squires, 2015). For those SMP herders who migrate to town, the outcome is very serious due to the transference of their grassland use rights to others. It is well known that these rented grasslands will be significantly degraded because without any extra supervision, the herder will likely fully use the plant biomass. Evidence from our surveys indicated that this is very common in Maqu, and the herders also regarded this as the most important factor causing the degradation of grasslands. In Nagqu, located in the Tibetan region, some herders also felt that grasslands not grazed would be degraded because plant regeneration would be suppressed by the build-up of plant litter. This might occur in a situation when the owner does not rent their grassland due to the rental income being too low. Overall, an unbalanced development strategy in urbanization has caused issues of waste of resources and environmental degradation as in other places in China (Cao et al., 2014b).

It is easier to implement formal institutions with the MMP than the SMP. For example, if a village is composed of the MMP, then the policymakers can supervise the delegates recommended by each MMP. In this case, the management cost is expected to be low and government policy is implemented completely due to the authority and position of the concerned delegates. If the same village is composed of the SMP, it is impossible for the policy-makers to supervise because the residents are very dispersed on the QTP.

For these reasons, we assigned nominally positive indicator values for the social system of the MMP, and nominally negative values for the SMP (see Table 2). Based on Table 2, we can infer that the resilience of the social system is about 0.9 for the MMP, and about -0.9 for the 
SMP, respectively, and that a lack of equity, cultural transmission and institutional arrangements may be the most serious problems for the SMP. Therefore, the resilience of the social system could be enhanced if the SMP herders would recognize these issues and deliberately improve the situation, especially the issues of cultural transmission and institutional arrangements. However, there is very little space for the SMP to achieve equitable forage and water resources utilization due to the limited grazing area.

\section{Overview of recommendations}

With acknowledgment of the difficulties in the systemic measurement and prediction of the resilience of land management within socialecological systems (Allen et al., 2005; Standish et al., 2014), researchers can select some key indicators to measure, quantitatively or qualitatively, its influences on the resilience of the whole system. In this study, the outcomes of two different grassland management patterns were compared on the basis of their grazing, ecological, economic and social systems.

The extensively collated data both from field measurements and the analyses of previous studies showed that plant and soil conditions under the MMP were better than under the SMP, due to the larger grazing areas or the prevalence of transhumance in the former. Also, because of the limited fencing and cooperation between households and informal institutions, the economic and social conditions under the MMP were better than the SMP, all of which can ameliorate the risk of entering unsustainable and undesirable developmental trajectories (Carpenter et al., 2001; Hua and Squires, 2015; Folke et al., 2002; Olsson et al., 2004; Schermer et al., 2016).

Conserving natural vegetation and maintaining resilience of the grasslands is basic to human, social and economic well-being (Biggs et al., 2012; Walker et al., 2002, 2006). It is also essential to alleviate or eliminate sources of conflict between regions that depend on river discharge from the QTP, which is the birthplace of Asia's primary rivers and provides water resources for about $40 \%$ of the world's population (Cao and Zhang, 2015). In order to achieve a "resilience orientation" of grassland management (Brown and Williams, 2015), stringent and strategic measures must be adopted to encourage the SMP to unite with the MMP (Li et al., 2007), and scientists, organizations and government agencies should be integrated into this effort (Dong and Sherman, 2015). Fortunately, a new law in October 2007 (the Cooperative Law) created an opportunity for the revitalization of traditional communal herding practices. A communal grazing system with seasonal rotation, dependent on the new law, was developed in Inner Mongolia (Tang and Gavin, 2015). Also, in recent years, a policy of specialized breeding was enforced on the QTP to achieve a scale effect, exemplifying yet another opportunity for the SMP to merge into the MMP system.

\section{Conclusion}

Due to its larger grazing areas or the prevalence of transhumance, plant and soil conditions under the multi-household management pattern (MMP) are more sustainable than under the single-household management pattern (SMP). Economic and social conditions are also more developed under the MMP. In summary, it is clear from this study that the resilience of grazing, ecological, economic and social systems under the MMP is higher than under the SMP, and thus the grassland contract policy may result in long-term problems in the QinghaiTibetan Plateau.

As grazing, ecological, social and economic systems interact with each other, the relationships between them and feedback mechanisms among them should be extensively studied in the future. In addition, objective quantitative approaches should be used to assess the resilience of each of these systems to gain more accurate and reliable results.

\section{Acknowledgements}

This study was supported by the National Natural Science Foundation of the Gansu Provincial Science and Technology Department (41461109), (1506RJZA124), and the Key Laboratory of Ecohydrology of the Inland River Basin, Chinese Academy of Science. Dr. R. C. Deo gratefully acknowledges the funding provided by the CAS Presidential International Fellowship Initiative Program (2016) and the University of Southern Queensland Academic Development and Outside Studies Program (ADOSP 2016). Prof. J. Adamowski gratefully acknowledges the funding provided by the NSERC Discovery and Accelerate grants.

\section{References}

Adger, W.N., Hughes, T.P., Folke, C., Carpenter, S.R., Rockström, J., 2005. Social-ecological resilience to coastal disasters. Science 309 (5737), 1036-1039. http://dx.doi. org/10.1126/science.1112122.

Adger, W.N., 2000. Institutional adaptation to environmental risk under the transition in Vietnam. Ann. Assoc. Am. Geogr. 90 (4), 738-758. http://dx.doi.org/10.1111/00045608.00220.

Al-Tabini, R., Al-Khalidi, K., Al-Shudiefat, M., 2012. Livestock, medicinal plants and rangeland viability in jordan's badia, through the lens of traditionaland local knowledge. Pastoralism 2 (2), 1-16. http://dx.doi.org/10.1186/2041-7136-2-4.

Allen, C.R., Gunderson, L., Johnson, A.R., 2005. The use of discontinuities and functional groups to assess relative resilience in complex systems. Ecosystems 8 (8), 958-966. http://dx.doi.org/10.1007/s10021-005-0147-x.

Anderies, J.M., Janssen, M.A., Walker, B.H., 2002. Grazing management, resilience, and the dynamics of a fire-driven rangeland system. Ecosystems 5 (1), 23-44. http://dx. doi.org/10.1007/s10021-001-0053-9.

Andersen, G.L., Krzywinski, K., Talib, M., Saadallah, A.E.M., Hobbs, J.J., Pierce, R.H., 2014. Traditional nomadic tending of trees in the red sea hills. J. Arid Environ. 106 (7), 36-44. http://dx.doi.org/10.1016/j.jaridenv.2014.02.009.

Anderson, D.M., Salick, J., Moseley, R.K., Ou, X.K., 2005. Conserving the sacred medicine mountains: a vegetation analysis of Tibetan sacred sites in northwest Yunnan. Biodivers. Conserv. 14 (13), 3065-3091. http://dx.doi.org/10.1007/s10531-0040316-9.

Ao, M., Ito, M., Ito, K., 2008. Floristic compositions of inner Mongolian grasslands under different land-use conditions. Grassl. Sci. 54, 173-178. http://dx.doi.org/10.1111/j. 1744-697X.2008.00121.x.

Assefa, E., Hans-Rudolf, B., 2016. Farmers'perception of land degradation and traditional knowledge in southern Ethiopia-Resilience and stability. Land Degrad. Dev. 27 (6), 1552-1561. http://dx.doi.org/10.1002/ldr.2364.

Ayala-Orozco, B., Gavito, M.E., Mora, F., Siddique, I., Balvanera, P., Jaramillo, V.J., Cotler, H., Romero-Duque, L.P., Martínez-Meyer, E., 2016. Resilienceof soil properties to land-use change in a tropical dry forest ecosystem. Land Degrad. Dev. http:// dx.doi.org/10.1002/ldr.2686.

Bengtsson, J., Angelstam, P., Elmqvist, T., Emanuelsson, U., Folke, C., Ihse, M., Moberg, F., Nyström, M., 2003. Reserves, resilience and dynamic landscapes. Ambio A: J. Hum. Environ. 32 (6), 389-396. http://dx.doi.org/10.1639/0044-7447(2003) 032[0389:RRADL]2.0.CO;2.

Berkes, F., Jolly, D., 2000. Adapting to climate change: social-ecological resilience in a Canadian Western Arctic Community. Conserv. Ecol. 5 (2), 213-218. http://dx.doi. org/10.5751/ES-00342-050218.

Biggs, R., Schlüter, M., Duan, B., Bohensky, E.L., Burnsilver, S., Cundill, G., Dakos, V., Daw, T.M., Evans, L.S., Kotschy, K., Leitch, A.M., Meek, C., Quinlan, A., RaudseppHearne, C., Robards, M.D., Schoon, M.L., Schultz, L., West, P.C., 2012. Toward principles for enhancing the resilience of ecosystem services. Environ. Resour. 37, 421-448. http://dx.doi.org/10.1146/annurev-environ - 051211-123836.

Brady, N.C., 1990. The nature and properties of soils, 7th Edition. Soil Sci. 5 (6), 190.

Briske, D.D., Bestelmeyer, B.T., Stringham, T.K., Shaver, P.L., 2008. Recommendations for development of resilience-based state-and-transition models. Rangel. Ecol. Manag. 61 (4), 359-367. http://dx.doi.org/10.2111/07-051.1.

Brown, E.D., Williams, B.K., 2015. Resilience and resource management. Environ. Manage. 56 (6), 1416-1427. http://dx.doi.org/10.1007/s00267-015-0582-1.

Cai, H., Li, W.J., 2016. A study on efficiency and equity of rangeland management on qinghai-Tibet plateau in different property right systems. J. Nat. Resour. 31 (8), 1302-1309. http://dx.doi.org/10.11849/zrzyxb.20141650. (in Chinese).

Cai, R.J., Min, W.Y., 2003. Thoughts on the problem of the present breeding in fence and its solution. J. Northw. Univ. Natl. Philos. Soc. Sci. 5, 41-44. http://dx.doi.org/10. 3969/j.issn.1001-5140.2003.05.006. (in Chinese).

Cao, S.X., Zhang, J.Z., 2015. Political risks arising from the impacts of large-scale afforestation on water resources of the Tibetan plateau. Gondwana Res. 28 (2), 898-903. http://dx.doi.org/10.1016/j.gr.2014.07.002.

Cao, J.J., Xiong, Y.C., Sun, J., Xiong, W.F., Guo, Z.D., 2011. Differential benefits of Multiand Single-Household grassland management patterns in the Qinghai-Tibetan Plateau of China. Hum. Ecol. 39 (2), 217-227. http://dx.doi.org/10.1007/s10745-0119384-0.

Cao, J.J., Yeh, E.T., Holden, N.M., Yang, Y.Y., Du, G.Z., 2013. The effects ofenclosures and land-use contracts on rangeland degradation on the Qinghai-Tibetan Plateau. J. Arid. Environ. 97 (12), 3-8. http://dx.doi.org/10.1016/j.jaridenv.2013.05.002. 
Cao, S.X., Lv, Y., Zheng, H.R., Wang, X., 2014a. Challenges facing china's unbalanced urbanization strategy. Land Use Policy 39 (39), 412-415. http://dx.doi.org/10.1016/ j.landusepol.2013.12.004.

Cao, S.X., Ma, H., Yuan, W.P., Wang, X., 2014b. Interaction of ecological andsocial factors affects vegetation recovery in china. Biol. Conserv. 180, 270-277. http://dx.doi.org/ 10.1016/j.biocon.2014.10.009.

Cao, J.J., 2011. Sustainable Utilization of Grassland in Qinghai-Tibet Plateau. Lanzhou University, Lanzhou, pp. 10-97 (in Chinese).

Carpenter, S., Walker, B., Anderies, J.M., Abel, N., 2001. From metaphor to measurement: resilience of what to what? Ecosystems 4 (8), 765-781. http://dx.doi.org/10.1007/ s10021-001-0045-9.

Chambers, J.C., Miller, R.F., Board, D.I., Pyke, D.A., Roundy, B.A., Grace, J.B., Schupp E.W., Tausch, R.J., 2014. Resilience and resistance of sagebrush ecosystems: implications for state and transition models and management treatments. Rangeland Ecol. Managt. 67 (5), 440-454. http://dx.doi.org/10.2111/REM-D-13-00074.1.

Chen, H., Zhu, T., 2015. The dilemma of property rights and indigenous institutional arrangements for common resources governance in China. Land Use Policy 42 (42), 800-805. http://dx.doi.org/10.1016/j.landusepol.2014.10.008.

Chen, L.F., He, Z.B., Du, J., Yang, J.J., Zhu, X., 2016. Patterns and environmental controls of soil organic carbon and total nitrogen in alpine ecosystems of northwestern China. Catena 37, 37-43. http://dx.doi.org/10.1016/j.catena.2015.08.017.

Ciftcioglu, G.C., 2017. Assessment of the resilience of socio-ecological production landscapes and seascapes: a case study from lefke region of north cyprus. Ecol. Indic. 73, 128-138. http://dx.doi.org/10.1016/j.ecolind.2016.09.036.

Coiffait-Gombault, C., Buisson, E., Dutoit, T., 2012. Are old mediterranean grasslands resilient to human disturbances? Acta Oecol. 43 (43), 86-94. http://dx.doi.org/10. 1016/j.actao.2012.04.011.

Craine, J.M., Ocheltree, T.W., Nippert, J.B., Towne, E.G., Skibbe, A.M., Kembel, S.W., Fargione, J.E., 2013. Global diversity of drought tolerance and grassland climatechange resilience. Nat. Clim. Change 3 (1), 63-67. http://dx.doi.org/10.1038/ nclimate1634.

Cumming, G.S., Barnes, G., Perz, S., Schmink, M., Sieving, K.E., Southworth, J., Binford, M., Holt, R.D., Stickler, C., Holt, T.V., 2005. An exploratory framework for the empirical measurement of resilience. Ecosystems 8 (8), 975-987. http://dx.doi.org/10. 1007/s10021-005-0129-z.

Cutter, S.L., Barnes, L., Berry, M., Burton, C., Evans, E., Tate, E., Webb, J., 2008. A placebased model for understanding community resilience to natural disasters. Glob. Environ. Change 18 (4), 598-606. http://dx.doi.org/10.1016/j.gloenvcha.2008.07. 013.

Darnhofer, I., 2014. Resilience and why it matters for farm management. Eur. Rev. Agric. Econ. 41 (3), 461-484. http://dx.doi.org/10.1093/erae/jbu012.

Dlamini, P., Chivenge, P., Manson, A., Chaplot, V., 2014. Land degradation impact on soil organic carbon and nitrogen stocks of sub-tropical humid grasslands in South Africa. Geoderma 235, 372-381. http://dx.doi.org/10.1016/j.geoderma.2014.07.016.

Dong, S.K., Sherman, R.E., 2015. Enhancing the resilience of coupled human and natural systems of alpine rangelands on the QinghaPlateau. Rangeland J. 37 (1), i-iii. http:// dx.doi.org/10.1071/rj14117.

Dong, Q.M., Zhao, X.Q., Wu, G.L., Chang, X.F., 2015. Optimization yak grazing stocking rate in an alpine grassland of Qinghai-Tibetan Plateau. China. Environ. Earth. Sci. 73 (5), 2497-2503. http://dx.doi.org/10.1007/s12665-014-3597-7.

Du, F.C., Zhang, S.H., 2013. Economic Transition of Pastoralism in Western. Intellectual Property Publishing House, China, Beijing (in Chinese).

Ekpo, U.F., Omotayo, A.M., Dipeolu, M.A., 2008. Prevalence of malnutrition among settled pastoral Fulani children in southwest Nigeria. BMC Res. Notes 1 (1), 1-7 http://dx.doi.org/10.1186/1756-0500-1-7.

Fassnacht, F.E., Li, L., Fritz, A., 2015. Mapping degraded grassland on the eastern Tibetan plateau with multi-temporal landsat 8 data-where do the severely degraded areas occur? Int. J. Appl. Earth. Obs. 42 (10), 115-127. http://dx.doi.org/10.1016/j.jag. 2015.06.005.

Fernandez-Gimenez, M.F., 2002. Spatial and social boundaries and the paradox of pastoral land tenure: a case study from post-socialist Mongolia. Hum. Ecol. 30 (1), 49-78. http://dx.doi.org/10.1023/A:1014562913014.

Fisichelli, N.A., Schuurman, G.W., Hoffman, C.H., 2016. Is 'resilience' maladaptive? towards an accurate lexicon for climate change adaptation. Environ. Manage. 57 (4), 1-6. http://dx.doi.org/10.1007/s00267-015-0650-6.

Flanagan, C., Laituri, M., 2004. Local cultural knowledge and water resource management: the wind river indian reservation. Environ. Manage. 33 (2), 262-277. http:// dx.doi.org/10.1007/s00267-003-2894-9.

Foggin, M., 2012. Pastoralists and wildlife conservation in western China: collaborative management within protected areas on the Tibetan Plateau. Pastoralism 2 (1), 1-19. http://dx.doi.org/10.1186/2041-7136-2-17.

Folke, C., Carpenter, S.R., Elmqvist, T., Gunderson, L., Holling, C.S., Walker, B., 2002. Resilience and sustainable development: building adaptive capacity in a world of transformations. Ambio 31 (5), 437-440. http://dx.doi.org/10.1579/0044-7447-31. 5.437 .

Folke, C., Carpenter, S.R., Walker, B., Scheffer, M., Chapin, T., Rockström, J., 2010. Resilience thinking: integrating resilience, adaptability and transformability. Ecol. Soc. 15 (4), 299-305.

Folke, C., 2006. Resilience: the emergence of a perspective for social-ecological systems analyses. Glob. Environ. Change 16 (3), 253-267. http://dx.doi.org/10.1016/j. gloenvcha.2006.04.002.

Franco, D., Luiselli, L., 2014. Shared ecological knowledge and wetland values:A case study. Land Use Policy 41 (4), 526-532. http://dx.doi.org/10.1016/j.landusepol. 2014.04.007.

Franzén, F., Hammer, M., Balfors, B., 2015. Institutional development for stakeholder participation in local water management-an analysis of two Swedishcatchments.
Land Use Policy 43, 217-227. http://dx.doi.org/10.1016/j.landusepol.2014.11.013. Gallopín, G.C., 2006. Linkages between vulnerability, resilience, and adaptive capacity. Glob. Environ. Change 16 (3), 293-303. http://dx.doi.org/10.1016/j.gloenvcha. 2006.02.004.

Grosse, G., Harden, J., Turetsky, M., McGuire, A.D., Camill, P., Tarnocai, C., Frolking, S., Schuur, E.A.G., Jorgenson, T., Marchenko, S., Romanovsky, V., Wickland, K.P., French, N., Waldrop, M., Bourgeau-Chavez, L., Striegl, R.G., 2011. Vulnerability of high-latitude soil organic carbon in North America to disturbance. J. Geophys. Res. 116 (3), 130-137. http://dx.doi.org/10.1029/2010JG001507.

Gunderson, L.H., 2000. Ecological resilience-in theory and application. Annu. Rev. Ecol. Syst. 31 (31), 425-439. http://dx.doi.org/10.1146/annurev.ecolsys.31.1.425.

Harris, R.B., 2010. Rangeland degradation on the Qinghai-Tibetan plateau: a review of the evidence of its magnitude and causes. J. Arid Environ. 74, 1-12. http://dx.doi. org/10.1016/j.jaridenv.2009.06.014.

Hirsch, P.R., Jhurreea, D., Williams, J.K., Murray, P.J., Scott, T., Misselbrook, T.H., Keith, W.T., Clark, I.M., 2016. Soil resilience and recovery: rapid community responses to management changes. Plant. Soil. 1-15. http://dx.doi.org/10.1007/s11104-0163068-x.

Holling, C.S., 1973. Resilience and stability of ecological systems. Annu. Rev. Ecol. Syst. 4 (4), 1-23. http://dx.doi.org/10.1146/annurev.es.04.110173.000245.

Hua, L., Squires, V.R., 2015. Managing China's pastoral lands: current problems and future prospects. Land Use Policy 43, 129-137. http://dx.doi.org/10.1016/j. landusepol.2014.11.004.

Hughes, T.P., Baird, A.H., Bellwood, D.R., Card, M., Connolly, S.R., Folke, C., Grosberg, R., Hoegh-Guldberg, O., Jackson, J.B.C., Kleypas, J., Lough, J.M., Marshall, P., Nyström, M., Palumbi, S.R., Pandolfi, J.M., Rosen, B., Roughgarden, J., 2003. Climate change, human impacts, and the resilience of coral reefs. Science 301 (5635), 929-933. http://dx.doi.org/10.1126/science.1085046.

Kühsel, S., Blüthgen, N., 2015. High diversity stabilizes the thermal resilience of pollinator communities in intensively managed grasslands. Nat. Commun. 6, 79-89. http://dx.doi.org/10.1038/ncomms8989.

Kerven, C., Robinson, S., Behnke, R., Kushenov, K., Milner-Gulland, E.J., 2016. Horseflies, wolves and wells: biophysical and socio-economic factors influencing livestock distribution in Kazakhstan's rangelands. Land Use Policy 52, 392-409. http://dx.doi. org/10.1016/j.landusepol.2015.12.030.

Klein, J.A., Yeh, E., Bump, J., Nyima, Y., Hopping, K., 2011. Coordinating environmental protection and climate change adaptation policy in resource-dependent communities: a case study from the Tibetan Plateau. In: In: Ford, J., Ford, L.B. (Eds.), Climate Change Adaptation in Developed Nations: From Theory to Practice, vol. 42. Springer, Netherlands, pp. 423-438. http://dx.doi.org/10.1007/978-94-007-0567-8.

Klimeš, Leoš, Hájek, M., Mudrák, Ondřej, Dančák, M., Preislerová, Z., Hájková, P., Jongepierová, I., Klimešová, J., 2013. Effects of changes in management on resistance and resilience in three grassland communities. Appl. Veg. Sci. 16, 640-649. http:// dx.doi.org/10.1111/avsc.12032.

Knapp, R.A., Hawkins, C.P., Ladau, J., Mcclory, J.G., 2005. Fauna of Yosemitenational park lakes has low resistance but high resilience to fish introductions. Ecol. Appl. 15 (3), 835-847. http://dx.doi.org/10.1890/04-0619.

Lebel, L., Anderies, J.M., Campbell, B., Folke, C., 2006. Governance and the capacity to manage resilience in regional social-ecological systems. Ecol. Soc. 11 (1), 1599-1604. http://dx.doi.org/10.5751/ES-01606-110119.

Li, W.J., Zhang, Q., 2009. Comprehending Rangeland Dilemmas: Understandingseveral Issues in Arid and Semi-Arid Rangeland Utilization Management. Economic Science Publishing House, Beijing (in Chinese).

Li, W.J., Ali, S.H., Zhang, Q., 2007. Property rights and grassland degradation:a study of the xilingol pasture, Inner Mongolia, China. J. Environ. Manage. 85 (2), 461-470. http://dx.doi.org/10.1016/j.jenvman.2006.10.010.

Liu, L.M., Zhao, Y.W., Xie, H., 2003. Study on regional characteristics of rangeland degradation of China and its control strategies for sustainable use and management. China Popul. Resour. Environ. 13 (4), 46-50 1002-2104(2003)04-0046-05 (in Chinese).

Looy, K.V., Lejeune, M., Verbeke, W., 2016. Indicators and mechanisms of stability and resilience to climatic and landscape changes in a remnant calcareous grassland. Ecol. Indic. 70, 498-506. http://dx.doi.org/10.1016/j.ecolind.2016.06.036.

Luthar, S.S., Cicchetti, D., 2000. The construct of resilience: implications for interventions and social policies. Dev. Psychopathol. 12 (4), 857-885. http://dx.doi.org/10.1017/ S0954579400004156.

Ma, W.M., Ding, K.Y., Li, Z.W., 2016. Comparison of soil carbon and nitrogen stocks at grazing-excluded and yak grazed alpine meadow sites in Qinghai-Tibetan plateau. China Ecol. Eng. 87, 203-211. http://dx.doi.org/10.1016/j.ecoleng.2015.11.040.

McCulloch, M., Falter, J., Trotter, J., Montagna, P., 2012. Coral resilience to ocean acidification and global warming through $\mathrm{pH}$ up-regulation. Nat. Clim. Change 2 (8), 623-627. http://dx.doi.org/10.1038/nclimate1473.

Mcgahey, D.J., 2011. Livestock mobility and animal health policy in southern Africa: the impact of veterinary cordon fences on pastoralists. Pastoralism 1 (1), 1-29. http://dx. doi.org/10.1186/2041-7136-1-14.

Miller, F., Osbahr, H., Boyd, E., Thomalla, F., Bharwani, S., Ziervogel, G., Walker, B., Birkmann, J., Leeuw, S.V.D., Rockstrom, J., Hinkel, J., Downing, T., Folke, C., Nelson, D., 2010. Resilience and vulnerability: complementary or conflicting concepts? Ecol. Soc. 15 (3), 11. http://www.ecologyandsociety.org/vol15/iss3/art11/.

Mumby, P.J., Hastings, A., Edwards, H.J., 2007. Thresholds and the resilience of Caribbean coral reefs. Nature 450 (7166), 98-101. http://dx.doi.org/10.1038/ nature06252.

Nelson, D.R., Adger, W.N., Brown, K., 2007. Adaptation to environmental change: contributions of a resilience framework. Annu. Rev. Environ. Resour. 32 (1), 395-419. http://dx.doi.org/10.1146/annurev.energy.32.051807.090348.

Ng, E.L., Patti, A.F., Rose, M.T., Schefe, C.R., Smernik, R.J., Cavagnaro, T.R., 2015. Do 
organic inputs alter resistance and resilience of soil microbial community to drying? Soil Biol. Biochem. 81, 58-66. http://dx.doi.org/10.1016/j.soilbio.2014.10.028.

Nkedianye, D., Leeuw, J.D., Ogutu, J.O., Said, M.Y., Saidimu, T.L., Kifugo, S.C., Kaelo, D.S., Reid, R.S., 2011. Mobility and livestock mortality in communally used pastoral areas: the impact of the 2005-2006 drought on livestock mortality in Maasailand. Pastoralism 1, 1-17. http://dx.doi.org/10.1186/2041-7136-1-17.

Nyström, M., Folke, C., Moberg, F., 2000. Coral reefs disturbance and resilience in a human-dominated environment. Trends Ecol. Evol. 15 (10), 413-420. http://dx.doi. org/10.1016/S0169-5347(00)01948-0.

Olff, H., Ritchie, M.E., 1998. Effects of herbivores on grassland plant diversity. Trends Ecol. Evol. 13 (7), 261-265. http://dx.doi.org/10.1016/S0169-5347(98)01364-0.

Oliver, T.H., Heard, M.S., Isaac, N.J.B., Roy, D.B., Procter, D., Eigenbrod, F., Freckleton, R., Hector, A., Orme, C.D.L., Petchey, O.L., Proença, Vânia., Raffaelli, D., Suttle, K.B., Mace, G.M., Martín-López, B., Woodcock, B.A., Bullock, J.M., 2015a. Biodiversity and resilience of ecosystem functions. Trends Ecol. Evol. 30 (11), 673-684. http://dx.doi. org/10.1016/j.tree.2015.08.009.

Oliver, T.H., Isaac, N.J.B., August, T.A., Woodcock, B.A., Roy, D.B., Bullock, J.M., 2015b. Declining resilience of ecosystem functions under biodiversityloss. Nat. Commun. 6, 10122. http://dx.doi.org/10.1038/ncomms10122.

Olsson, P., Folke, C., Berkes, F., 2004. Adaptive comanagement for building resilience in social-ecological systems. Environ. Manage. 34 (1), 75-90. http://dx.doi.org/10. 1007/s00267-003-0101-7.

Paton, D., Millar, M., Johnston, D., 2001. Community resilience to volcanic hazard consequences. Nat. Hazard. 24 (2), 157-169. http://dx.doi.org/10.1023/ A:1011882106373.

Pazkagan, T., Shachak, M., Zaady, E., Karnieli, A., 2014. Evaluation of ecosystem responses to land-use change using soil quality and primary productivity in a semi-arid area, israel. Agric. Ecosyst. Environ. 193, 9-24. http://dx.doi.org/10.1016/j.agee. 2014.04.024.

Peacock, B.C., Hikuroa, D., Morgan, T., 2012. Watershed-scale prioritization ofhabitat restoration sites for non-point source pollution management. Ecol. Eng. 42 (9), 174-182. http://dx.doi.org/10.1016/j.ecoleng.2012.01.005.

Perz, S.G., Shenkin, A., Barnes, G., Cabrera, L., Carvalho, L.A., Castillo, J., 2012. Connectivity and resilience: a multidimensional analysis of infrastructure impacts in the southwestern Amazon. Soc. Indic. Res. 106 (2), 259-285. http://dx.doi.org/10. 1007/s11205-011-9802-0.

Plummer, R., Armitage, D., 2007. A resilience-based framework for evaluating adaptive co-management: linking ecology, economics and society in a complex world. Ecol. Econ. 61 (1), 62-74. http://dx.doi.org/10.1016/j.ecolecon.2006.09.025.

Ptackova, J., 2011. Sedentarisation of tibetan nomads in China: implementationof the nomadic settlement project in the Tibetan Amdo area; Qinghai and Sichuan Provinces. Pastoralism 1 (1), 1-11. http://dx.doi.org/10.1186/2041-7136-1-4.

Qin, Y., Feng, Q., Holden, N.M., Cao, J., 2016. Variation in soil organic carbon by slope aspect in the middle of the Qilian mountains in the upper Heihe river basin, China. Catena 147, 308-314. http://dx.doi.org/10.1016/j.catena.2016.07.025.

Quinlan, A.E., Berbés-Blázquez, M., Haider, L.J., Peterson, G.D., 2016. Measuring and assessing resilience: broadening understanding through multiple disciplinary perspectives. J. Appl. Ecol. 53 (3), 677-687. http://dx.doi.org/10.1111/1365-2664. 12550.

Rist, L., Felton, A., Nyström, M., Troell, M., Sponseller, R.A., Bengtsson, J., Österblom, H., Lindborg, R., Tidàker, P., Angeler, D.G., Milestad, R., Moen, J., 2014. Applying resilience thinking to production ecosystems. Ecology 5 (6), 1-11. http://dx.doi.org/ 10.1890/ES13-00330.1.

Robinett, D., Miller, D., Bedunah, D., 2008. Central Afghanistan rangelands: a history of tribal rule, grazing, war, and rebuilding. Rangelands 30 (4), 2-12. http://dx.doi.org/ 10.2111/1551-501X(2008)30[2:CAR]2.0.CO;2.

Robinson, L.W., Ericksen, P.J., Chesterman, S., Worden, J.S., 2015. Sustainableintensification in drylands: what resilience, and vulnerability, can tell us. Agric. Syst. 135, 133-140. http://dx.doi.org/10.1016/j.agsy.2015.01.005.

Rocamora-Montiel, B., Glenk, K., Colombo, S., 2014. Territorial management contracts as a tool to enhance the sustainability of sloping and mountainousolive orchards: evidence from a case study in southern spain. Land Use Policy 41 (41), 313-324. http:// dx.doi.org/10.1016/j.landusepol.2014.06.016.

Salick, J., Amend, A., Anderson, D., Hoffmeister, K., Gunn, B., Fang, Z., 2007. Tibetan sacred sites conserve old growth trees and cover in the easternHimalayas. Biodivers. Conserv. 16 (3), 693-706. http://dx.doi.org/10.1007/s10531-005-4381-5.

Sara, K., Nico, B., 2015. High diversity stabilizes the thermal resilience of pollinator communities in intensively managed grasslands. Nat. Commun. 6, 79-89. http://dx. doi.org/10.1038/ncomms8989.

Schermer, M., Darnhofer, I., Daugstad, K., Gabillet, M., Lavorel, S., Steinbacher, M., 2016. Institutional impacts on the resilience of mountain grasslands:an analysis based on three European case studies. Land Use Policy 52, 382-391. http://dx.doi.org/10. 1016/j.landusepol.2015.12.009.

Schlüter, M., Pahl-wostl, C., 2007. Mechanisms of resilience in common-pool resource management systems: an agent-based model of water use in a river basin. Ecol. Soc. 12 (2), 375-386. http://dx.doi.org/10.5751/ES-02069-120204.

Scull, P., Cardelús, C.L., Klepeis, P., Woods, C.L., Frankl, A., Nyssen, J., 2016. The resilience of Ethiopian church forests: interpreting aerial photographs, 1938-2015. Land Degrad. Dev. 28 (2), 450-458. http://dx.doi.org/10.1002/ldr.2633.

Sgrò, C.M., Lowe, A.J., Hoffmann, A.A., 2011. Building evolutionary resiliencefor conserving biodiversity under climate change. Evol. Appl. 4 (2), 326-337. http://dx.doi. org/10.1111/j.1752-4571.2010.00157.x.

Shen, X.L., Sheng, L., Chen, N., Li, S.Z., McShea, W.J., Lu, Z., 2012. Does science replace traditions? Correlates between traditional Tibetan culture andlocal bird diversity in Southwest China. Biol. Conserv. 145, 160-170. http://dx.doi.org/10.1016/j.biocon. 2011.10.027.

Singh, N.J., Bhatnagar, Y.V., Lecomte, N., Fox, J.L., Yoccoz, N.G., 2013. No longer tracking greenery in high altitudes: pastoral practices of Rupshu nomads and their implications for biodiversity conservation. Pastoralism 3 (1), 3-16. http://dx.doi. org/10.1186/2041-7136-3-16.

Spears, B.M., Ives, S.C., Angeler, D.G., Allen, C.R., Birk, S., Carvalho, L., Cavers, S., Daunt, F., Morton, D.R., Pocock, M.J.O., Rhodes, G., Thackeray, S.J., 2015. Forum: effective management of ecological resilience-are we there yet? J. Appl. Ecol. 52 (5), 1311-1315. http://dx.doi.org/10.1111/1365-2664.12497.

Standish, R.J., Hobbs, R.J., Mayfield, M.M., Bestelmeyer, B.T., Suding, K.N., Battaglia, L.L., Eviner, V., Hawkes, C.V., Temperton, V.M., Cramer, V.A., Harrisi, J.A., Funk, J.L., Thomask, P.A., 2014. Resilience in ecology: abstraction, distraction, or where the action is? Biol. Conserv. 177 (9), 43-51. http://dx.doi.org/10.1016/j.biocon. 2014.06.008.

Tang, R.F., Gavin, M.C., 2015. Degradation and re-emergence of the commons:The impacts of government policies on traditional resource management institutions in China. Environ. Sci. Policy 52, 89-98. http://dx.doi.org/10.1016/j.envsci.2015.04. 0232 .

Tompkins, E.L., Adger, W.N., 2004. Does adaptive management of natural resources enhance resilience to climate change? Ecol. Soc. 9 (2), 1-14. http://dx.doi.org/10. 5751/ES-00667-090210.

Tu, Q., Bulte, E., Tan, S.H., 2011. Religiosity and economic performance: micro-econometric evidence from Tibetan area. China Econ. Rev. 22 (1), 55-63. http://dx.doi. org/10.1016/j.chieco.2010.09.008.

Veeck, G., Li, Z., Yu, F., Emerson, C., 2015. The effects of China's environmental protection policies on pasture quality and the activities of small-scale herders in Songpan County, Western Sichuan. Environ. Monit. Assess 187 (6), 368. http://dx.doi.org/10. 1007/s10661-015-4601-8.

Vij, S., Narain, V., 2016. Land, water and power: the demise of common property resources in periurban Gurgaon, India. Land Use Policy 50 (50), 59-66. http://dx.doi. org/10.1016/j.landusepol.2015.08.030.

Vogel, A., Scherer-Lorenzen, M., Weigelt, A., 2012. Grassland resistance and resilience after drought depends on management intensity and species richness. PLoS One 7 (5) e36992. http://dx.doi.org/10.1371/journal.pone.0036992.

Walker, B., Carpenter, S.R., Anderies, J.M., Abel, N., 2002. Resilience management in social-ecological systems: a working hypothesis for a participatoryapproach. Ecol. Soc. 6 (1), 840-842. http://dx.doi.org/10.5751/ES-00356-060114.

Walker, B.H., Anderies, J.M., Kinzig, A.P., Ryan, P., 2006. Exploring resiliencein socialecological systems through comparative studies and theory development: introduction to the special issue. Ecol. Soc. 11 (1), 709-723. http://dx.doi.org/10.5751/ES01573-110112.

Wang, J., Wang, Y., Li, S., Qin, D., 2016. Climate adaptation, institutional change, and sustainable livelihoods of herder communities in northern Tibet. Ecol. Soc. 21 (1). http://dx.doi.org/10.5751/es-08170-210105.

Yan, Z.L., Wu, N., Doriji, Y., 2005. A review of rangeland and privatization and its implication in the Tibetan Plateau, China. Nomadic Peoples 9, 31-51. http://dx.doi. org/10.3167/082279405781826155.

Yang, Y.Y., 2012. The Impact Studies of Plateau Different Grazing Patterns of Grassland Degradation. Master's Thesis. Lanzhou University (in Chinese).

Yeh, E.T., Gaerrang, 2011. Tibetan pastoralism in neoliberalising China: continuity and change in Gouli. Area 43 (2), 165-172. http://dx.doi.org/10.1111/j.1475-4762. 2010.00976.x.

Yeh, E.T., 2013. The politics of conservation in contemporary rural China. J. Peasant Stud. 40 (6), 1165-1188. http://dx.doi.org/10.1080/03066150.2013.859575.

YontenNyima, 2012. From 'Retire Livestock, Restore Rangeland' to the Compensation for Ecological Services: State Interventions into Rangeland Ecosystems and Pastoralism in Tibet. Unpublished PhD Dissertation. Department of Geography, CU Boulder.

Yoshihara, Y., Mizuno, H., Yasue, H., No, P., Ito, T.Y., 2013. Nomadic grazingimproves the mineral balance of livestock through the intake of diverse plant species. Anim. Feed. Sci. Technol. 184 (1-4), 80-85. http://dx.doi.org/10.1016/j.anifeedsci.2013. 06.007.

You, Q.G., Xue, X., Peng, F., Xu, M.H., Duan, H.C., Dong, S.Y., 2014. Comparison of ecosystem characteristics between degraded and intact alpine meadow in the Qinghai-Tibetan Plateau, China. Ecol. Eng. 71, 133-143. http://dx.doi.org/10.1016/ j.ecoleng.2014.07.022.

Zhang, L., Miao, Q.L., 2007. Precipitation changes in the Tibetan plateau during the last four decades. Arid Land Geogr. 30 (2), 241-246. http://dx.doi.org/10.3321/j. issn:1000-6060.2007.02.014. (in Chinese). 